\title{
Nutritional assessment of corn wet feed in Nili Ravi Buffalo (Bubalus bubalis)
}

\author{
Sana Najeeb ${ }^{1}$, Asif Javaid ${ }^{*}$, Kashif Siddiq ${ }^{2}$, Muhammad Akhtar ${ }^{3}$, Mahr- \\ un-Nisa ${ }^{4}$ and Muhammad Shuaib Khan ${ }^{1}$ \\ 1. Faculty of Veterinary \& Animal Sciences, Gomal University, D. I. Khan-29200-Pakistan \\ 2. Assistant disease investigator officer, district disease diagnostic laboratory, Khanewal-Pakistan \\ 3. RV \& F Directorate GHQ Rawalpindi-Pakistan \\ 4. GC University, Faisalabad-Pakistan \\ *Corresponding author's email: asifjavaid165@gmail.com \\ Citation \\ Sana Najeeb, Asif Javaid, Kashif Siddiq, Muhammad Akhtar, Mahr-un-Nisa and Muhammad Shuaib Khan. \\ Nutritional assessment of corn wet feed in Nili Ravi Buffalo (Bubalus bubalis). Pure and Applied Biology. Vol. 7, \\ Issue 3, pp998-1006. http://dx.doi.org/10.19045/bspab.2018.700118
}

\begin{tabular}{llll}
\hline \hline Received: 27/04/2018 & Revised: 09/07/2018 & Accepted: 13/07/2018 & Online First: 17/07/2018 \\
\hline
\end{tabular}

\section{Abstract}

Four rumen fistulated buffalo bulls were used in Latin Square Design $(4 \times 4)$ to inspect the impact of replacement of corn grains with corn wet feed $(\mathrm{CWF})$ on nutrients digestibility, rumen characteristics (rumen $\mathrm{pH}$ and ammonia $\mathrm{N}$ ) and nitrogen $(\mathrm{N}$ ) balance. The bulls were fed restricted diets. Diets were formulated isocaloric (ME $2.30 \mathrm{Mcal} / \mathrm{kg}$ ) and isonitrogenous $(12.55 \%$ crude protein (CP). The CWF0 (control diet) had no CWF, while CWF10, CWF20 and CWF30 diets contained CWF 10, 20 and 30\%, correspondingly. Experimental duration was eighty days. The CP and dry matter $(\mathrm{DM})$ intakes did not differ $(\mathrm{P}>0.05)$ across all diets because of restricted diets. High intake $(\mathrm{P}<0.05)$ of neutral detergent fiber $(\mathrm{NDF})$ was noted in animals fed CWF30 than animals fed CWF0, it was similar to those fed CWF10 and CWF20 diets. The CP, DM and NDF digestibility was high $(\mathrm{p}<0.05)$ in bulls fed CWF10 diet as compared to bulls fed CWF0, CWF20 and CWF30 diets, whereas, these were similar (P>0.05) among bulls fed CWF30, CWF20 and CWF0 diets. The $\mathrm{N}$ balance was positive in all bulls. High $\mathrm{N}$ balance $(\mathrm{P}<0.05)$ was noted in animals fed CWF10 and CWF20 diets compared to those fed other experimental diets. Rumen pH at $0,3,6$ and 9 hours after feeding was same across all diets. Rumen ammonia $\mathrm{N}$ was different $(\mathrm{P}<0.05)$ at 3,6 and 9 hours after feeding, however, it was same at 0 hour. In conclusion, replacing $10 \%$ corn grains with CWF showed improved digestibility, rumen characteristics and $\mathrm{N}$ retention of bulls.

Keywords: Buffalo bull; Digestibility; N balance; Ruminal ammonia-N; Ruminal pH

\section{Introduction}

Recently native and exogenous livestock breeds are being raised with manipulation of feed ingredients to fulfill nutritional requirements of peoples of developing countries. However, Pakistan is still facing scarcity of feed ingredients for potential ruminant production [1]. Animal nutritional needs cannot be met resulting under fed because of this scarcity of feeds. The existing resources of feeds are 24 and $38 \%$ scarce in total digestible nutrient and crude protein (CP), correspondingly [1]. There are various substitutes to fulfill this nutrient deficiency. The agro-industrial byproducts (AIBP) are considered significant feed stuffs that can 
meet the feed scarcity in ruminant animals [2] because the concentrates share in total feed resources is approximately $77 \%$ total digestible nutrients and 9\% $\mathrm{CP}$ share of the total concentrate comes from AIBP in Pakistan [3].

The AIBP feed resources (wheat bran, rice polishing, sugarcane pith, molasses, corn cobs, corn gluten meal 60 and 30\%, corn bran, oil seed cake, corn steep liquor, hulls and meals etc.) can not only meet the animal nutrients requirement but have also the potential to make the diet economical [1]. However, their nutritional evaluation is essential before inclusion in ruminant's diet [4]. Biological and chemical evaluation of AIBP for ruminant animals may expose a new opportunity to minimize the gap between nutrient demand and their availability [5].

Wet corn gluten feed (WCGF) is a potential feed ingredient for beef and dairy animals [6]. It is fed to animals as a dry or wet form. Procedure of milling of WCGF initiate with the separation of the maize grain and removing of any foreign particle. The corn kernel is soaked in a blend of sulfur dioxide and water which results to swell up the kernel. During the procedure of steeping/soaking, the nutrients moved into the water, which is called the corn steep liquor. The liquor is squeezed, concentrated and the remaining is called corn gluten feed or corn wet feed (CWF) [7].

The CWF is good source of protein, moderately high digestible fiber, less in starch and low in vegetable oil [8]. On the basis of its characteristics, the CWF can be fed in high amount to ruminant animals. It may be considered as energy source in spite of its increased portion of fiber. Fiber is slightly more digestible in wet CWF than its dry condition results in more intake of wet compared to dry form [8]. Many studies have reported improved production with inclusion of CWF in the diet but few have stated rumen effects [9].

The CWF is byproduct of corn processing industry and contains 14\% CP, 40\% DM, $80 \%$ total digestible nutrients, $12 \%$ crude fiber and holds high contents of moisture. High moisture content in CWF is major constraints for its higher inclusion level in the diet of ruminants. Higher moisture contents ingredients are more prone to fungal growth and ultimately toxin production in CWF which is injurious to animal production and health [10-12]. Nutritionists are in efforts to preserve CWF by using in total mix ration along with other feeding stuffs containing less contents of moisture which will prevent it from fungal growth. However, the inclusion of CWF in the diet of ruminant animals can only be recommended after its nutritional evaluation by conducting its thorough studies in ruminant animals [13]. The objective of this experiment was to assess the impact of gradually replacement of CWF on nutrients digestibility, $\mathrm{N}$ balance and rumen characteristics in fistulated Nili Ravi buffalo bulls.

\section{Materials and methods}

Four ruminally fistulated Nili-Ravi buffalo bulls $(550 \pm 20 \mathrm{~kg})$ were used in Latin Square Design $(4 \times 4)$ to find out the effect of gradual replacement of corn grain with CWF on digestibility of nutrients, $\mathrm{N}$ balance and rumen characteristics (rumen $\mathrm{pH}$ and ammonia N). Four iso-nitrogenous (12.55\%) and iso-caloric $(2.30 \mathrm{Mcal} / \mathrm{kg}$ ) total mixed rations were formulated using different levels of CWF (Table 1). The CWF was secured from Rafhan Maize Products Co. Ltd. The chemical composition of CWF is presented in (Table 2). Faisalabad. Control diet (CWF0) contained $30 \%$ of corn grain and $0 \% \mathrm{CWF}$ on DM basis, whereas rations CWF10, CWF20 and CWF30 contained 20,10 and 0\% corn and 10, 20 and $30 \% \mathrm{CWF}$ on DM basis, correspondingly. Bulls were fed restricted diets@1\% of body weight on DM basis. The bulls were kept on concrete floor and in 
individual pens. The bulls fed two-time a day. The availability of water was ensured for 24 hours. Experimental duration was 80 days. The bulls fed for 15 days, the first 10 days served as adjustment period whereas the next 5 days as collection period. After 20, 40 and 60 days, re-randomization of diets was done and same procedure was replicated. The total collection method procedure was used to find out nutrient digestibility [14]. Complete urine collection was done by the method defined by Javaid et al. [15]. Daily collection of feces and urine of each bull was done, properly weighed, well mixed and $20 \%$ of it was sampled. The feces dried at $55{ }^{\circ} \mathrm{C}$ in oven. Dried fecal samples were composited at the termination of each collection phase and 10 $\%$ of this was used for chemical analysis. The $10 \%$ urine sample was collected after acidifying urine with $50 \% \mathrm{H}_{2} \mathrm{SO}_{4}$. The urine sample was well preserved at $-20^{\circ} \mathrm{C}$. The urine samples were composited at the end of collection phase and $10 \%$ of the composited sample was used for chemical analysis [4]. Rumen sampling was done at 3, 6, 9 and 12 hours of post feeding in morning to determine $\mathrm{NH}_{3}-\mathrm{N}$ and rumen $\mathrm{pH}$. Subsequently the sample was pressed through cheesecloth (4 layers). Approximately $50 \mathrm{ml}$ of rumen liquor was preserved after acidifying with $3 \mathrm{ml}$ of 6 $\mathrm{N} \mathrm{HCI}$ to end the process of fermentation.

Table 1. Ingredients and chemical composition of experimental diets (\%)

\begin{tabular}{|c|c|c|c|c|}
\hline & \multicolumn{5}{|c|}{ Diets $^{1}$} \\
\hline Ingredients & CWF 0 & CWF 10 & CWF 20 & CWF 30 \\
\hline Corn cobs & 30.00 & 30.00 & 30.00 & 30.00 \\
\hline Corn & 30.00 & 20.00 & 10.00 & 0.00 \\
\hline Corn wet feed & 0.00 & 10.00 & 20.00 & 30.00 \\
\hline Maize gluten 30\% & 9.00 & 10.00 & 9.00 & 8.50 \\
\hline Maize gluten 60\% & 5.00 & 5.00 & 5.00 & 5.00 \\
\hline Maize oil cake & 5.00 & 4.00 & 4.00 & 3.50 \\
\hline Corn steep liquor & 5.00 & 4.00 & 4.00 & 4.00 \\
\hline Enzose & 14.00 & 15.00 & 15.00 & 15.00 \\
\hline Maize oil & 1.00 & 1.00 & 2.00 & 3.00 \\
\hline Dicalcium Phosphate & 1.00 & 1.00 & 1.00 & 1.00 \\
\hline Total & $\mathbf{1 0 0}$ & $\mathbf{1 0 0}$ & $\mathbf{1 0 0}$ & $\mathbf{1 0 0}$ \\
\hline Chemical Composition & & & & 71.08 \\
\hline Dry matter \% & 85.38 & 80.70 & 75.80 & 12.59 \\
\hline Crude protein \% & 12.57 & 12.59 & 12.56 & 40.65 \\
\hline Neutral detergent fiber & 35.66 & 37.51 & 39.11 & 2.33 \\
\hline ME ${ }^{2}$ Mcal/Kg & 2.40 & 2.30 & 2.30 & CWF30 \\
\hline
\end{tabular}

${ }^{1} \mathrm{CWF} 0$ represents the control diets having 30\% corn and 0\% corn wet feed, while CWF10, CWF20 and CWF30 refer to diets having 10, 20 and 30\% corn wet feed replacing with corn, respectively.

${ }^{2}$ Metabolizable Energy 
Feed samples and fecal samples were analysed for DM and CP [16]. The samples were dried at $105^{\circ} \mathrm{C}$ for 24 hours in hot air oven to determine DM [16]. The $\mathrm{N}$ was determined by Kjeldahl method and then $\mathrm{N}$ was multiply with 6.25 factor to calculate $\mathrm{CP}$ [16]. The NDF was determined by using method of Van Soest et al. [17]. During each collection period at $17^{\text {th }}$ day ruminal liquor was taken from the rumen of cannulated bulls and $\mathrm{pH}$ was determined by Ohaus $\mathrm{pH}$ meter (Model, STATER3000). Ruminal NH3-N was determined by direct distillation and titration carried out by Kjeldhal's method [18]. General linear model of SPSS 17.0 was used to analyse the data by the analysis of variance technique in
Latin Square Design [19]. Duncan's new multiple range test was used for means separation.

\section{Results and discussion}

No difference $(\mathrm{P}>0.05)$ in $\mathrm{CP}$ and $\mathrm{DM}$ intakes among the treatments was only due to method of feeding because all animal were on restricted feed intake. While, higher $(\mathrm{P}<0.05)$ intake of NDF was noted in bulls fed CWF30 diet followed by bulls fed CWF20, CWF10 and CWF0 diet, correspondingly (Table 3). The increasing trend in intake of NDF bulls fed diet having varying level of CWF was because of its increased dietary contents of NDF (35.66, 37.51, 39.11 and 40.65\%) with increasing inclusion level of CWF.

Table 2. Chemical composition of corn wet feed

\begin{tabular}{|c|c|}
\hline Dry matter \% & 37 \\
\hline Crude protein \% & 14 \\
\hline Fat $\%$ & 2.5 \\
\hline $\mathrm{ME}^{1} \mathrm{Kcal} / \mathrm{Kg}$ & 1518 \\
\hline
\end{tabular}

${ }^{1}$ Metabolizable Energy

Table 3. Effect of replacing different levels of corn grains with corn wet feed on nutrients intake and digestibility in buffalo bulls

\begin{tabular}{|c|c|c|c|c|c|}
\hline \multicolumn{7}{|c|}{ Diets $^{1}$} \\
\hline Items & CWF0 & CWF10 & CWF20 & CWF30 & SE $^{2}$ \\
\hline Intake (Kg/day) & & & & & \\
\hline Dry matter & 5.35 & 5.35 & 5.35 & 5.35 & \pm 0.857 \\
\hline Crude protein & 0.673 & 0.672 & 0.673 & 0.674 & \pm 0.473 \\
\hline Neutral detergent fiber & $1.91^{\mathrm{b}}$ & $2.01^{\mathrm{ab}}$ & $2.09^{\mathrm{ab}}$ & $2.17^{\mathrm{a}}$ & \pm 0.01 \\
\hline Digestibility\% & & & & & \\
\hline Dry matter & $65.07^{\mathrm{b}}$ & $70.19^{\mathrm{a}}$ & $66.41^{\mathrm{b}}$ & $66.86^{\mathrm{b}}$ & \pm 0.668 \\
\hline Crude protein & $60.48^{\mathrm{b}}$ & $66.05^{\mathrm{a}}$ & $62.65^{\mathrm{b}}$ & $62.45^{\mathrm{b}}$ & \pm 0.0417 \\
\hline Neutral detergent fiber & $59.98^{\mathrm{b}}$ & $66.83^{\mathrm{a}}$ & $61.08^{\mathrm{b}}$ & $58.87^{\mathrm{b}}$ & \pm 0.947 \\
\hline
\end{tabular}

${ }^{1}$ CWF0 represents the control diets having 30\% corn and 0\% corn wet feed, while CWF10, CWF20 and CWF30 refer to diets having 10, 20 and $30 \%$ corn wet feed replacing with corn, respectively.

${ }^{2}$ Standard error

${ }^{\mathrm{a}, \mathrm{b}}$ Means within row with different superscripts differ $(P<0.05)$

The DM digestibility was high $(\mathrm{P}<0.05)$ in bulls fed CWF10 diet as compared with bulls fed CWF0, CWF20 and CWF30 diets. Same findings were observed for $\mathrm{CP}$ and NDF digestibility. The lower $\mathrm{CP}, \mathrm{NDF}$ and DM digestibility in bulls fed CWF30 and CWF20 diets might be related to increased addition of CWF. Less digestibility of nutrients by bulls fed CWF0 diet might be because of large particle, floating in rumen liquor having low 
specific gravity and earlier passing from rumen compared with particles having small size and high gravity $[20,21]$. Another possible reason might be increased passage rate of digesta from rumen to rectum [20-22]. The results of this study are supported by scientists [23] who stated low digestibility of $\mathrm{CP}$, NDF and DM with increase in the inclusion WCGF level in the cattle diet. Another possible reason may be related to increasing dietary moisture because of increasing the inclusion CWF level which might had enhanced diet passage rate in digestive tract as reported by $[24,25]$. Allen and Grant [21] and Crystal et al. [22] reported that $\mathrm{CP}, \mathrm{DM}$ and $\mathrm{NDF}$ digestibility was decreased with increased WCGF level. It might be due to low ruminal $\mathrm{NH}_{3}-\mathrm{N}$ concentration because Javaid et al. [15] reported low digestibility of DM with low ruminal $\mathrm{NH}_{3}-\mathrm{N}$ concentration. The low digestibility in bulls fed higher corn grain level might be related to nutrients uncoupling in rumen restricting microbial fermentation of the nutrients [26].

The total $\mathrm{N}$ excreted, urinary $\mathrm{N}$ and $\mathrm{N}$ intake were same by bulls across all diets (Table 4). While, fecal $\mathrm{N}$ was high $(\mathrm{P}>0.05)$ in bulls fed CWF0 diet. Retention of $\mathrm{N}$ was high $(\mathrm{P}>0.05)$ in bulls fed CWF20 and CWF10 diets followed by bulls fed CWF0 and CWF30 diet. As the bulls fed restricted diets thus non-significant difference in $\mathrm{N}$ excreted, urinary $\mathrm{N}$ and $\mathrm{N}$ intake was observed in bulls across all diets. Rich et al. [27] noted same findings regarding fecal $\mathrm{N}$ that was higher (33.60\%) as compared to control. This might be because of greater bypass protein. Findings of this study are in agreement with findings of other researchers $[28,29]$. As the CWF supplies a mixture of free amino acids, ammonia and peptides for the growth of microbes and microbial protein synthesis therefore it can be considered valuable for the rumen.

Table 4. Effect of replacing different levels of corn grains with corn wet feed on $\mathbf{N}$ balance in buffalo bulls

\begin{tabular}{|c|c|c|c|c|c|}
\hline \multicolumn{7}{|c|}{ Diets $^{1}$} \\
\hline Items (g/day) & CWF0 & CWF10 & CWF20 & CWF30 & SE $^{2}$ \\
\hline Nitrogen Intake & 107.68 & 107.6 & 107.8 & 107.8 & \pm 1.722 \\
\hline Fecal nitrogen & $43.42^{\mathrm{a}}$ & 36.42 & 40.2 & 40.58 & \pm 0.881 \\
\hline Urinary nitrogen & 52.35 & 53.13 & 54.85 & 51.93 & \pm 1.365 \\
\hline Total excreted nitrogen & 94.79 & 88.43 & 95.05 & 92.48 & \pm 1.917 \\
\hline Nitrogen balance & $12.88^{\mathrm{b}}$ & $16.27^{\mathrm{a}}$ & $15.57^{\mathrm{a}}$ & $15.31^{\mathrm{b}}$ & \pm 0.466 \\
\hline
\end{tabular}

${ }^{1}$ CWF0 represents the control diets having $30 \%$ corn and $0 \%$ corn wet feed, while CWF10, CWF20 and CWF30 refer to diets having 10, 20 and $30 \%$ corn wet feed replacing with corn, respectively.

${ }^{2}$ Standard error

${ }^{\mathrm{a}, \mathrm{b}}$ Means within row with different superscripts differ $(P<0.05)$

The rumen $\mathrm{pH}$ was unaltered in bulls fed all diets (Table 5). The increase in CWF level in the diet caused decreased ruminal $\mathrm{pH}$ which might be because of sufficient provision of long particle size essential for normal rumen function resulting maintenance of rumen $\mathrm{pH}$. Same results were also reported by [7, 30] with enhancing the concentration of dietary WCGF. Feeds deficient in long particle size are more fermentable [20] resulting more acid production with subsequent drop in rumen $\mathrm{pH}$. The particle size and $\mathrm{pH}$ are related, the diets having high WCGF had more part of longer particles (greater than 8 $\mathrm{mm})$. This might had increased chewing activity. Enhanced activity of chewing might had resulted to stimulate the production of salivary buffer resulting no change in rumen $\mathrm{pH}[31,32]$. It is observed that even adding $\mathrm{CWF}$ decreased ruminal $\mathrm{pH}$, it might because 
of provision of adequate effective fiber by $30 \%$ CWF diet to maintain rumen function. The CWF is fermented rapidly in rumen as compared to corn grain $[33,34]$. The cows fed rapidly fermentable feeds have acidic rumen $\mathrm{pH}$ because of readily fermentation of CWF as compared to corn grain [35]. It describes the linear increase in acidic rumen $\mathrm{pH}$ resulting the feeding of greater quantity of CWF to bulls in this experiment.

Rumen $\mathrm{NH}_{3}-\mathrm{N}$ concentration was observed at $0,3,6$, and 9 hours post feeding in animals fed diets having different CWF level as expressed in (Table 6). Rumen $\mathrm{NH}_{3}-\mathrm{N}$ concentration before feeding ( 0 hour) was same in bulls across all diets. Higher $(\mathrm{p}<0.05)$ rumen $\mathrm{NH}_{3}-\mathrm{N}$ concentration at 3 hours post feeding was noticed in bulls fed CWF10 diet than those fed other diets. Similar trend in $\mathrm{NH}_{3}-\mathrm{N}$ concentration was noticed at 6 hours post feedings. Rumen $\mathrm{NH}_{3}-\mathrm{N}$ concentration was high $(\mathrm{P}<0.05)$ in bulls fed CWF10 diet at 9 hours post feeding than bulls fed CWF0 diet but it was similar to those fed CWF20 and CWF30 diet. Higher concentration of rumen $\mathrm{NH}_{3}-\mathrm{N}$ concentration in bulls fed CWF10 was related to high digestibility of $\mathrm{CP}$. Schroeder et al. [7] also reported similar results with enhancing level of WCGF in the diets of Holstein cows. The $\mathrm{NH}_{3}-\mathrm{N}$ concentration in rumen have been explained to increase when urea, molasses and starch was supplemented to non-lactating cow from non-forage fiber like WCGF [36], the dietary portion of nonstructural carbohydrate was increased [37] resulting increased amount of starch digestion in the rumen [38]. However, the concentration of rumen $\mathrm{NH}_{3}-\mathrm{N}$ in bulls fed diets having CWF was close to optimum rumen $\mathrm{NH}_{3}-\mathrm{N}[39,40]$ healthier to improve synthesis of microbial protein and feed digestibility.

Table 5. Effect of replacing different levels of corn grains with corn wet feed on Rumen pH in buffalo bulls

\begin{tabular}{|c|c|c|c|c|c|}
\hline \multicolumn{7}{|c|}{ Diets $^{1}$} \\
\hline Items & CWF0 & CWF10 & CWF20 & CWF30 & SE $^{2}$ \\
\hline pH 0h & 6.52 & 6.45 & 6.35 & 6.25 & \pm 0.235 \\
\hline pH 3h & 6.10 & 6.05 & 5.95 & 5.83 & \pm 0.253 \\
\hline pH 6h & 6.30 & 6.10 & 6.03 & 5.97 & \pm 0.314 \\
\hline pH 9h & 6.45 & 6.30 & 6.30 & 6.17 & \pm 0.293 \\
\hline
\end{tabular}

${ }^{1}$ CWF0 represents the control diets having 30\% corn and 0\% corn wet feed, while CWF10, CWF20 and CWF30 refer to diets having 10, 20 and 30\% corn wet feed replacing with corn, respectively.

${ }^{2}$ Standard error

Table 6. Effect of replacing different levels of corn grains with corn wet feed on rumen ammonia concentration in buffalo bulls

\begin{tabular}{|c|c|c|c|c|c|}
\hline \multicolumn{7}{|c|}{ Diets $^{1}$} \\
\hline Items (mg/dl) & CWF0 & CWF10 & CWF20 & CWF30 & SE $^{2}$ \\
\hline $\mathrm{NH}_{3}-\mathrm{N} \mathrm{0} \mathrm{h}$ & 25.2 & $25.2^{\mathrm{a}}$ & 26.2 & 26.2 & 1.7 \\
\hline $\mathrm{NH}_{3}-\mathrm{N} 3 \mathrm{~h}$ & $25.5^{\mathrm{b}}$ & $27.8^{\mathrm{a}}$ & $26.4^{\mathrm{ab}}$ & $26.1^{\mathrm{ab}}$ & 1.4 \\
\hline $\mathrm{NH}_{3}-\mathrm{N} 6 \mathrm{~h}$ & $26.1^{\mathrm{b}}$ & $28.4^{\mathrm{a}}$ & $27.7^{\mathrm{ab}}$ & $27.0^{\mathrm{ab}}$ & 3.6 \\
\hline $\mathrm{NH}_{3}-\mathrm{N} 9 \mathrm{~h}$ & $23.2^{\mathrm{b}}$ & $27.3^{\mathrm{a}}$ & $26.1^{\mathrm{a}}$ & $25.5^{\mathrm{a}}$ & 3.5 \\
\hline
\end{tabular}

${ }^{1}$ CWF0 represents the control diets having 30\% corn and 0\% corn wet feed, while CWF10, CWF20 and CWF30 refer to diets having 10, 20 and $30 \%$ corn wet feed replacing with corn, respectively.

${ }^{2}$ Standard error

${ }^{\mathrm{a}, \mathrm{b}}$ Means within row with different superscripts differ $(P<0.05)$ 


\section{Conclusion}

From this study, nutrients digestibility, N balance, ruminal $\mathrm{pH}$ and ruminal $\mathrm{NH}_{3}-\mathrm{N}$ for diets in which the corn grains were replaced gradually with corn wet feed showed best response at inclusion level $10 \%$ of corn wet feed in bull diet. But it requires additional lactation trials having more number of buffaloes necessary before giving any recommendation for its inclusion in rations of lactating Nili-Ravi buffaloes.

\section{Authors' contributions}

Conceived and designed the experiments: MU Nisa, S Najeeb, M Akhtar \& A Javaid, Performed the experiments: S Najeeb \& K Siddiq, Analyzed the data: S Najeeb, A Javaid \& MS Khan, Contributed materials/ analysis/ tools: MU Nisa, M Akhtar \& K Siddiq, Wrote the paper: A Javaid, S Najeeb \& MS Khan.

\section{Acknowledgements}

We acknowledge the Rafhan Maize Products Company, Faisalabad to provide feed ingredients for the conduction of this study.

\section{References}

1. Sarwar M, Khan MA, Nisa M \& Iqbal Z (2002). Dairy Industry in Pakistan: A Scenario. Int J Agri Bio 3: 420-432.

2. Akram M (1990). Pakistan Animal Feed Resources in Asia and Pacific. Asian Productivity Organization, Tokyo.

3. Sarwar M, Shahzad MA, Nisa M, Bhatti SA \& Tauqir NA (2012). Enhancing buffalo productivity through usage of low quality feed stuffs. J Anim Plant Sci 22: 128-132.

4. Sarwar M, Khan MA \& Nisa M (2004). Effect of organic acid or fermentable carbohydrates on digestibility and nitrogen utilization of urea treated wheat straw in buffalo bulls. Aust J Agri Research 55: 223-228.

5. Nisa M, Sarwar M \& Khan MA (2004). Influence of ad libitum feeding of urea treated wheat straw with or without corn steep liquor on intake, in situ digestion kinetics, nitrogen metabolism and nutrient digestion in Nili-Ravi buffalo bulls. Aust J Agri Research 55: 235-239.

6. Taylor EG, Lemenager RP \& Stewart KR (2017). Using corn gluten feed in post-partum diets of young beef cows to optimize reproductive performance. Translational Anim Sci 1: 1-8.

7. Schroeder JW (2003). Optimizing the level of wet corn gluten feed of lactating dairy cows. J Dairy Sci 86: 844-851.

8. Scott T, Klopfenstein T, Shain D \& Klemesrud M (1997). Wet corn gluten feed as a source of rumen degradable protein for finishing steers. Nebraska Beef Cattle Rep. USA 67: 70-72.

9. Gunderson SL, Guilar AA, Johnson DE \& Olson D (1988). Nutritional value of wet corn gluten feed for sheep and lactating dairy cows. J Dairy Sci 71: 1204-1210.

10. Iheshiulor OOM, Esonu BO, Chuwuka OK, Omede AA, Okoli IC \& Ogbuewu IP (2011). Effects of mycotoxins in animal nutrition: A Review. Asian $J$ Anim Sci 5: 19-33.

11. Anukul N, Vangnai K \& Mahakarnchanakul W (2013). Significance of regulation limits in mycotoxin contamination in Asia and risk management programs at the national level. J Food Drug Analys 21: 227-241.

12. Rodrigues I (2014). A review on the effects of mycotoxins in dairy ruminants. Anim Prod Sci http://dx.doi.org/10.1071/AN13492.

13. Kononoff PJ, Lvanand SK \& Klopfenstein TJ (2006). Estimation of proportion of feed protein digested in the small intestine of cattle consuming wet corn gluten feed. J Dairy Sci 91: 23772385.

14. Williams PEV, Innes GM \& Brewer A (1984). Ammonia treatment of straw via the hydrolysis of urea Effect of dry 
matter and urea concentration on the rate of hydrolysis by urea. Anim Feed Sci \& Tec 11: 103-113.

15. Javaid A, Shahzad MA, Nisa MN \& Sarwar M (2011). Ruminal dynamics of ad libitum feeding in buffalo bulls receiving different level of degradable protein. Livestock Sci 135:89-102.

16. AOAC (1990). Association of official analytical chemists. Official Methods of Analysis. $15^{\text {th }}$ edition, Arlington, Virginia, Washington DC.

17. Van Soest PJ, Roberston JB \& Lewis BA (1991). Carbohydrate methodology, metabolism and nutritional implications in dairy cattle.Methods for dietary fibre, neutral detergent fibre and non-starch polysaccharides in relation to animal nutrition. J Dairy Sci 74: 3583-3597.

18. AOAC (1984) Official Methods of Analysis. 14th Edition, Association of Official Analytical Chemists, Arlington, VA.

19. Steel RG, Torrie JH \& Dickey DA (1996). Principles and Procedures of Statistics.A Biometrical Approach. $3^{\text {rd }}$ edition. McGraw Hill Book Co. Inc. New York, USA.

20. Grant RJ Colenbrander VF \& Mertens DR (1990). Milk fat depression in dairy cows: Role of silage particle size. $J$ Dairy Sci 73: 1834-1842.

21. Allen DM \& Grant RJ (2000). Interactions between forage and wet corn gluten feed as sources of fiber in diets for lactating dairy cows. J Dairy Sci 83: 322331.

22. Crystal D Rolfe BK Meyer N Klopfenstein TJ \& Klopfenstein TJ (2010). Fiber digestibility and rumen $\mathrm{pH}$ for diets containing wet corn gluten feed or wet distillers grains with soluble. Nebraska Beef Cattle Reports. USA, 7779.

23. Abouheif MA KraideesMS \& AlSelbood BA (1999). The utilization of rumen content-barley meal in diets of growing lambs. Asian-Aust J AnimSci 12: $1234-1240$.

24. Cooper RJ Milton CT Klopfenstein TJ Scott TL Wilson CB \& Mass RA (2002).Effect of corn processing on starch digestion and bacterial crude protein flow in finishing cattle. $J$ Dairy Sci 80: 797-804.

25. Wickersham EE, Shirley JE, Titgemeyer EC, Brouk MJ, DeFrain JM, Park AF, Johnson DE \& Ethington RT (2004). Response of lactating dairy cows to diets containing wet corn gluten feed or a raw soybean hull-corn steep liquor pellet. $J$ Dairy Sci 87: 3899-3911.

26. Fellner V \& Belyea RL (1991). Maximizing gluten feed in corn silage diets for dairy cows. J Dairy Sci 74: 961005.

27. Rich AR, Erickson GE, Klopfenstein TJ, Luebbe MK, Benton JR \& Griffin WA (2010). Feeding increased amounts of wet distillers grains plus solubles on feedlot cattle performance. J Anim Sci 88: 126.

28. Kononoff PJ, Ivan SK \& Klopfenstein TJ (2007). Estimation of the proportion of feed protein digested in the small intestine of cattle consuming wet corn gluten feed. J Dairy Sci 90: 2377-2385.

29. Flis SA \& Wattiaux MA (2005). Effects of parity and supply of rumen-degraded and undegraded protein on production and nitrogen balance in Holsteins. $J$ Dairy Sci 88: 2096-2106.

30. Lammers BP, Buckmaster DR \& AJ Heinrichs (1996). A simple method for the analysis of particle sizes of forage and total mixed rations. J Dairy Sci 79: 922-928.

31. Kay RN (1966). The influence of saliva on digestion in ruminants. World Review of Nutrition and Dietetics. Processing co-products manual. AAFCO publication. pp 13-17. 
32. Balch CC (1971). Proposal to use time spent chewing as an index of the extent to which diets for ruminants possess the physical property of fibrousness characteristics of roughages. British $J$ Nutr 26: 383-392.

33. Armentano LE \& Pereira M (1997). Measuring the effectiveness of fiber by animal response trials. J Dairy Sci 80: 416-1425.

34. Firkins JL (1997). Effect of feeding nonforage fiber sources on site of fiber digestion. J Dairy Sci 80: 1426-1437.

35. Oba M \& Allen MS (2003). Effects of corn grain conservation method on feeding behavior and productivity of lactating dairy cows at two dietary starch concentrations. J Dairy Sci 86: 174-183.

36. Fadel JG, Uden $\mathrm{P}$ \& Robinson $\mathrm{PH}$ (1987). Effect of nitrogen and energy supplements on intake and digestion of oat straw by non-lactating dairy cows. $J$ Agri Sci 109: 503-517.

37. MacGregor CA, Stokes MR, Hoover WH, Leonard HA, Junkins LL, Sniffen
CJ \& Mailman RW (1983). Effect of dietary concentration of total nonstructural carbohydrate on energy and nitrogen metabolism and milk production of dairy cows. J Dairy Sci 66: 39-55.

38. MaCarthy RD, Klusmeyer Jr TH, Vicini JL, Clark JH \& Nelson DR (1989). Effects of sources of protein and carbohydrate on ruminal fermentation and passage of nutrients to the small intestine of lactating cows. J Dairy Sci 72: 2002-2016.

39. Perdok HB \& Leng RA (1990). Effect of supplementation with protein meal on the growth of cattle given a basal diet of untreated or ammoniated rice straw. Asian-Aust J Anim Sci 3: 269-279.

40. Wanapat M \& Pimpa O (1999). Effect of ruminal NH3-N levels on ruminal fermentation, purine derivatives, digestibility and rice straw intake in swamp buffaloes. Asian-Aust J Anim Sci 12:904-907. 